\title{
The Role of Jewish Philanthropic Associations in Large Cities of Central and Eastern Europe in the Interwar Period. ON THE EXample Of L'VIV (1918-1939)
}

\author{
Wacław Wierzbieniec \\ (University of Rzeszow) \\ e-mail: wacwie@univ.rzeszow.pl
}

Key words: aid for children, charity, Jews, L'viv, philanthropic associations, poor students

\begin{abstract}
Between the years 1918 and 1939, philanthropic associations played a major social role in L'viv, as did in other large Jewish communities in Central and Eastern Europe. The aim of this research paper is to present and discuss selected Jewish associations providing assistance to children, students in secular schools and youth studying at universities. It has to be pointed out that their high level of activity was an expression of the modernization processes taking place among the Jewish population and, clearly, the enhancement of these processes.
\end{abstract}

\section{Preliminary remarks}

The aim of this discussion is to determine to what extent the large urban concentrations of the Jewish population in Central and Eastern Europe influenced the character of the existing philanthropic associations and their establishments.

In interwar L'viv, Jewish philanthropic associations functioned within practically all social groups and circles of the Jewish population, often forming a specific bond between these circles or an important element of the bonding of these circles. However, some of them were also a more than social in nature. Through their activities, they reached out to varying degrees to people in need - mainly children, disabled people, the elderly, the sick and other people in need of financial assistance. This also included Jewish students studying at L'viv's universities, which was one of the specific features of Jewish charity in the great cities of Central and Eastern Europe.

The interwar period in Central and Eastern Europe was marked by intensification of modernization processes among the Jewish population. This was most visible in its large concentrations in cities with developed infrastructure, being centres of public administration, and constituting large centres of industry, trade, education or science.

The relatively rapid modernization of the Jewish population in large cities of Central and Eastern Europe such as L'viv, which were also large Jewish centres, included 
philanthropy and social assistance. In L'viv, with regard to Jewish philanthropy and social welfare a very visible element of that modernization was the scope of activities of organizations aimed at helping children and youth studying in vocational schools and the ones who undertook vocational, professional service. It had an impact on the socalled stratification of the Jewish population and enhanced activities addressed to students of general secondary schools, gymnasiums and high schools, and to youth studying at universities.

L'viv, the third largest Jewish settlement in Poland after Warsaw and Lodz, was inhabited by 99,595 people who professed Judaism in 1931. The Jewish population of L'viv was quite young demographically. Children aged 0-9 years constituted 15.0\% of the total Jewish population of L'viv in 1921, and $16.2 \%$ in 1931 . In the same years, however, one unfavourable process was observed for the Jewish population was a decrease in the percentage of young people among the total Jewish population. Between 1921 and 1931, the percentage of Jewish youth aged 10-19 decreased from 22.4\% to $14.9 \%$. This process may indicate a gradual ageing of the Jewish population. ${ }^{1}$

The modernization of selected organizations providing assistance to Jewish youth was reflected in the modern forms of their activities, the same as those widely practised among the remaining non-Jewish population of L'viv, both Polish and Ukrainian. Thus, these forms and the scope of their activities were very clearly derived from the traditional cultural "ghetto" of the Jews, outside the circles of Orthodoxy and Hasidism. The activities carried out by these modern organizations were also conducive to integration with the Polish population on the linguistic and cultural levels. As an expression of the modernization processes taking place among the Jewish population, these organizations also very clearly promoted the deepening and strengthening of these processes among the Jewish youth, facilitating their access to work in crafts and industry (in fields that were not traditional Jewish professions), as well as studying in secondary schools and universities, which were secular in nature.

As a result, the processes of modernizing the Jewish population, which were particularly visible in the large cities of Central and Eastern Europe such as L'viv, influenced the formation of Jewish philanthropic organizations of a modern character. The establishment of new philanthropic associations, however, did not cause the existing philanthropic associations to lose their significance. New associations of a modern character were complementary to those of a traditional nature that already existed.

\footnotetext{
${ }^{1}$ Wierzbieniec 2000: 290, 306.
} 


\section{Aid for children of preschool age and for young people studying in vocational schools and taking up professional vocational training, enhancing the purpose of the so-called stratification of the Jewish population $^{2}$}

Modern forms of social welfare could already be seen regarding the care of a Jewish child of preschool age. These were Jewish orphanages, which had the same character as Polish or Ukrainian ones. An example of this is the Jewish orphanage on Bernstein Street run by the Society for the Orphanages of Jewish Children. The Society was established in January 1914, but due to wartime events, population migration, and the occupation of L'viv by Russians, it developed its activities only after the end of the World War I, and functioned throughout the Second Republic of Poland. ${ }^{3}$

The society's statutory goal was to establish and run child shelters for poor parents who were followers of Judaism. In addition, it was to look after Jewish children in general and, in particular, to support the idea of shelters, with all means proving appropriate and effective. The sources of income for the society's activities were annual contributions from members of the society, subsidies from institutions such as the Jewish Community of L'viv and the L'viv City Council, income from public collections, including street collections, and, where possible, parents' fees for the care of children by the caretaker. ${ }^{4}$

The modern character of the society was evidenced by the fact that its members were almost exclusively women, including those with higher university education. They were distinguished by their high social status and their support of (or relationships with) the Zionist movement, and some of them belonged to WIZO (Women's International Zionist Organization). Most of them were the wives of lawyers, doctors, journalists, industrialists, wealthy merchants or professors of L'viv junior high schools and high schools, as well as L'viv universities. In 1929, the Society had about 200 members, and at that time Paulina Reiserov was its chair. In 1935, however, Sydonia Schutz presided over the Society as the chairwoman.

Having developed its activities, in the 1930s the society took care of about 80 preschool-age children (coming from poor families, or orphans and half-orphans). They lived in orphanages, modern care and educational institutions providing a substitute form of care and upbringing.

The process of modernization was reflected, among other things, in the fact that the Board of the Society for the Orphanages of Jewish Children hired professional care and educational staff with appropriate pedagogical qualifications to work in the orphanages. These were lay educators whose task was to initiate the individual development of each child and prepare them for school. They conducted educational and care work with the use of methods and means of upbringing proposed by modern pedagogy. As

${ }^{2}$ The so-called stratification was to involve changes in the current professional structure of the Jewish population, which was characterised by a very high share of Jews in trade. In order to change the current professional structure, it was attempted that as many Jews as possible would take up employment in agriculture, industry and crafts. It was mainly Zionists who postulated it.

${ }^{3}$ DALO, f. 110, op. 1, spr. 132: 31.

${ }^{4}$ Ibid.: 37. 
a result, the qualifications of the educators employed in the Jewish orphanage were similar to those of the Christian ones. ${ }^{5}$ For example, in 1933 the head of the Jewish orphanage was Stefania Gottlieb, a graduate of the State Orphanage Seminary in L'viv, and Cecylia Ritel, who had completed a private course and a supplementary course of the State Seminary in L'viv. The doctor responsible for the medical care of the children was Dr. Sonia Lowenstein. ${ }^{6}$

In the orphanage, neglected and orphaned Jewish children found a new home. The orphanage provided them with adequate psychological and physical care. The teachers taught them the basic principles of ethics and correct use of the Polish language, to which a lot of attention was paid. Their time was full of practical activities, gymnastics, talks, songs, and games. Particular emphasis was placed on hygiene and the physical development of the children. They were fed plentiful and tasty food three times a day, and they received clothes (e.g. winter coats) and shoes. Moreover, every year the children stayed in at a summer camp in the building of the Society for the Orphanages of Jewish Children in Brzuchowice, a small spa town of suburban L'viv. According to the report for March 1937 to March 1939, in order to obtain additional funds needed to maintain the orphanage and the summer camp in Brzuchowice, the Society's Management Board organized fundraising in the streets and among the society's members, and they also organized a bridge-dancing event. These measures contributed to the partial renovation of the summer camps facilities in Brzuchowice and the renovation of the orphanage rooms. In addition, new chairs were bought and those that were broken were repaired, and new bed linens were purchased to replace those no longer fit for use. ${ }^{7}$

In the ongoing processes of modernization of the Jewish community in L'viv, with respect to children of preschool age and youth taking up professional activity, the Society of Summer Camps and Horticultural Protection for Jewish Children and Youth, which had its seat at 4 Henryka Pollaka Street, also played an important role. In 1927, the society's facilities included Protection for the Abandoned and Orphaned Jewish Children and the Club of Boys at 54 Janowska Street, the Orphanage Facility at 8 Zborowska Street, the Vocational School Boarding House at 78 Janowska Street, and Farm Sygniówka near L'viv. At that time, the Society was headed by Dr. Maks Schaff, and the Management Board included people who held doctorate's degrees. ${ }^{8}$

In order to support its institutions, The Society of Summer Camps and Horticultural Protection for Jewish Children and Youth raised funds from the contributions of its members. Funds for the activities were also obtained from the Central Committee for the Care of Jewish Orphans in L'viv (in 1927 the subsidy from that Committee covered $35 \%$ of the maintenance costs of the Orphans' Institute), the Jewish community in L'viv, the magistrate of the city of L'viv, Joint (J.D.C.), and the L'viv Breweries.

${ }^{5}$ Ibid.: 2, 39-47.

${ }^{6}$ Łapot 2011: 131.

${ }^{7}$ DALO, f. 110, op. 1, spr. 132: 2. The town of Brzuchowice, not far from Lviv, gained great popularity among Lviv Jews in the interwar period as a summer resting place. Colonies for children and youth were also organized there by other Jewish organization; Jakimyszyn 2014: 88-89.

${ }^{8}$ The Management Board was composed of: Ignacy Friedman, Róża Frostigowa - wife of a well-known Zionist, MP Mojżesz Frostig, Max Glaserman, Ignacy Jager, Dr. Oswald Pinsker, Dr. Ada Reichenstein, Dr. Mischel Sucher; Sprawozdanie Towarzystwa Kolinji i Ochronek Ogrodniczych 1928: 2. 
In all the institutions of the society, individual development of each pupil was initiated. Each pupil was provided with separate documentation recording information on their behaviour, learning progress and health status. From time to time, on the basis of this documentation, educators, pedagogues and doctors discussed each student. This was also an effort to establish which profession would be suitable for each individual child. ${ }^{9}$

In 1927, 70 poor children of preschool age who could not count on proper parental care stayed in the orphanage. Children stayed in the building from 8:30 am to 3:30 pm, where they also received breakfast and lunch, and if necessary, underwear, clothing and footwear. They were cared for by educators with high pedagogical qualifications. As a result, the orphanage was run in accordance with the requirements of the latest pedagogical methods and directions. The educational classes for children were conducted according to the program, which were also applied to the Polish orphanages in L'viv. A great deal of attention was paid to physical education, and to the children's continuous contact with nature: frequent excursions and field trips were organized. ${ }^{10}$

The establishment and development of another institution of the Society of Summer Camps and Horticultural Protection for Jewish Children and Youth, namely the Orphans' Institution, was supported mainly by the well-known L'viv social activist Anzelm Vogel, who died in 1927. It was intended for orphans (boys and girls) up to the age of 14 , but it was predominantly aimed at orphaned children aged 6-8. Taking care of the intellectual development of the children was one of the most important aims of that institution. Evening talks were also organized, mainly devoted to the history and culture of Jews. The pupils were required to read books and write reports on the texts they had read. A lot of attention was paid to religious education. The children were encouraged to take part in a synagogue choir, which performed in the Temple Synagogue. In 1927, a house of prayer for the children was created in this Orphans' Institution. Physical education of children was also taken care of. Most of these children were sent to summer camps or vacationed in private holiday homes. ${ }^{11}$

The so-called stratification of the Jewish population was visibly enhanced by the increased participation of Jews in crafts and agriculture within a program carried out by the Summer Camps and Horticultural Protection Society for Jewish Children and Young People, the Craftsmen's Boarding School, and the Agricultural Farm.

The Craftsmen's Boarding School was intended for poor Jewish boys who, after graduating from primary school, learned craftsmanship in vocational schools and private crafts companies. According to the rules of the Craftsmen's Boarding School, boys aged 14-16 were allowed to stay there, and only in exceptional cases could they stay until the age of 17, when being given the opportunity to earn and support themselves, they had to leave the school. In reality, however, young people up to the age of 19 remained under the care of school if they had difficulties in finding a job that would enable them to earn their living on their own. In 1926, 39 boys aged 14-19 remained under the care of school. Of these, 28 lived permanently in the school and the others, due to a lack of space, lived with private individuals who were remunerated by the school management.

\footnotetext{
${ }^{9}$ Ibid: : 5, 7.

${ }^{10}$ Ibid.: 6, 13-14.

${ }^{11}$ Ibid.: 6, 8-9.
} 
However, these boys, like the boys living in the school, also ate in the school canteen. They also received underwear, clothing and footwear as needed.

The Craftsmen's Boarding School also attached great importance to the upbringing and broadening of the boys' knowledge. One of the most important educational goals was to deepen the Jewish national consciousness of the students. The boys were obliged to take part in classes on Jewish history, Hebrew language, ethics and Jewish literature, 5 hours a week. Moreover, in order for the boys to become members of society aware of their rights in the future, they were taught the Constitution of the Polish state and the provisions of the social security system. The school also had its own library with books on nature and technology and works of fiction. ${ }^{12}$ In accordance with the intention of the Society of Summer Camps and Horticultural Protection for Jewish Children and Youth, the boys attending the Craftsmen's Boarding School had "[...] in the future to create an avant-garde of an intelligent Jewish craftsman, aware of their tasks and goals". ${ }^{13}$

Poor Jewish youth cared for by the Society of Summer Camps and Horticultural Protection for Jewish Grandparents and Youth studied at the Agricultural Farm. In 1927, there were 18 students (orphans and half-orphans), who also had the opportunity to learn the locksmith's profession in a workshop on the farm. A report by the Society of Cologne and Horticultural Protection for Jewish Grandparents and Young People, covering the years 1926-1927, states that the agricultural farm in Sygniówka had been in operation for a long time. "The work in the reporting period continued the efforts made in previous years to stratify the orphanage youth and to create a cultural type of Jewish farmer and a healthy craftsman who loved his profession". ${ }^{14}$

The Boys' Club created by the Society of Summer Camps and Horticultural Protection for Jewish Children and Youth was a unique event among the Jewish community of L'viv regarding philanthropic activities.

The Boys' Club was innovative not only in L'viv, but also on a national scale. In the 1920s, such clubs were already quite common in Western Europe, and especially in the USA. They were known as "boys' clubs" and were of great educational importance, as they protected homeless young people from the influence of the street and its destructive effects. The seat of the Boys' Club was located in the building of the boarding house. It gathered poor orphaned Jewish boys. In 1927, 112 boys benefited from its activities, mainly graduates of Jewish orphanages from L'viv and other similar institutions, who studied in L'viv in vocational schools and gymnasiums, took apprenticeships in crafts and started work, but were not able to earn a full, independent living. They were therefore forced, at least to a certain extent, to accept material aid. Members of the Boys' Club enjoyed free lunches and dinners, received underwear, clothes, and soap, and could also take advantage of free baths. Some members also received fixed subsidies to pay for their flats. The activities of the Boys' Club included courses for illiterate people, courses in Hebrew, courses in Hebrew and Jewish literature, as well as talks mainly in the field of technology and handicrafts. As a result, this type of activity also contributed to raising the intellectual level of the boys. ${ }^{15}$

\footnotetext{
12 Ibid:: 10 .

${ }^{13}$ Ibid:: 11.

${ }^{14}$ Ibid:: 12.

${ }^{15}$ Ibid.: 7, 14-15.
} 


\section{Support measures for students of general secondary schools - gymnasiums and high schools}

In the process of modernizing the Jewish community in L'viv during the Second Polish Republic, more and more attention was paid to educating young people in the gymnasiums and high schools created as a result of the education reform in the 1930s. The Jewish youth studying in them gained wider opportunities for intellectual development and professional careers, which was extremely important as those students were later able to take up studies at secular universities.

With regard to the aid activities addressed to students of the general secondary schools, the gymnasiums and high schools, the "Care" Society for the Support of Jewish High School Youth deserves special attention. ${ }^{16}$ It was established in 1899 on the initiative of the L'viv Zionist community and developed relatively extensive activity before the World War I, providing material aid to poor Jewish youth (including orphans) studying in general secondary schools. Before the World War I, as well as in the interwar period, L'viv Zionists played an important role in the activities of the Society. ${ }^{17}$

In 1937, the Society had as many as 360 members, who were mainly part of the Jewish intelligentsia of L'viv. At the beginning of the 1930s, Dr. Adolf Schorr was Chair of the Society's Board of Directors. He was succeeded in 1935 by Dr. Oswald Pinsker, and in 1938 Dr. Rubin Muhlbauer became the Chair. ${ }^{18}$

The society's statutory goal was to support poor Jewish high school students in L'viv, in particular by providing them with assistance with enrolment fees (a oneoff enrolment fee), books, school uniforms, tuition fees (a fee for private and social school education), and health resorts. The society also aimed to provide students with free medical advice and medication at a reduced price, if necessary, and to act as an intermediary in providing tutoring to students who needed it. In addition, the poorest pupils were supplied with clothes and shoes as needed. For example, in the school year 1930/1931, 37 new items of clothing, 44 pairs of shoes and 5 coats were distributed.

The funds for the activities were provided by members' contributions, donations from private individuals and subsidies from the L'viv Jewish community. In order to raise funds, various events were also organized: concerts, theatrical performances and balls of great reputation in L'viv. ${ }^{19}$

In the mid-1930s, as a result of the negative effects of the economic crisis and the growing pauperisation of the Jewish community, the society began to experience difficulties in obtaining sufficient funds for its activities. The number of poor pupils in need of assistance had also increased. As a result, it was decided that aid for poor pupils should be limited to providing them with sufficient funds to pay tuition fees, i.e. tuition fees for private gymnasiums and high schools. Although these schools were private, they were very popular with the Jewish youth of L'viv, boys and girls alike. ${ }^{20}$ It should also be noted that

${ }^{16}$ Łapot 2016: 502.

${ }^{17}$ Before the World War I, the Society's Board of Directors included, among others, leading Galician Zionists Jakub Bodek and Abraham Korkis; Łapot 2011: 150.

${ }^{18}$ DALO, f. 110, op. 1, spr. 129: 1, 5, 8.

${ }^{19}$ Ibid:: 10-11.

${ }^{20}$ Ibid.: 6. 
in the interwar period, Jewish youth in L'viv were more frequently attending mainstream secondary schools, where anti-Semitic sentiments were growing. ${ }^{21}$

Poor students who were no longer able to be provided with clothes, food, medicine or school textbooks were sent to other Jewish philanthropic organizations. These organizations were adequately informed about the necessity and type of help for the students who needed it. In the school year 1935/1936 the society provided support for school fees in the amount of Zloty 6,248 and support for the purchase of shoes only in the amount of PLN 14. In the school year 1936/1937, the society's expenditure on school fees for students amounted to Zloty 6,230, and expenditure on clothing for was Zloty $15 .^{22}$

Although L'viv Zionists played an important role in the Society's activities, its apolitical character was declared and only students' financial condition and progress in education were taken into account when providing financial support to them. "Our society enjoys the kindness of almost all the local intelligentsia, because it has been developing its activities for the benefit of poor schoolchildren for many years. We also emphasize that our Society is completely depoliticized and cross-party, that the Department of our Society is composed of representatives of various political directions and that the granting of assistance in this or that form is decided only by the poverty and urgency of a given student." ${ }^{23}$

\section{Scope and forms of assistance for students}

An important feature of the ongoing modernization processes of the Jewish community in large cities of Central and Eastern Europe was the relatively high share of Jews among university students, mainly at universities. In L'viv, this was largely possible thanks to extensive philanthropic activities, material support received by students from various Jewish organizations, mainly connected with the Zionist movement, which raised funds for this purpose among a relatively wide circle of the Jewish community, and thanks to Jewish student organizations, which attached great importance to self-help activities.

Already during the period of Galicia's autonomy, and especially at the beginning of the $20^{\text {th }}$ century, L'viv had many Jewish student associations, whose activities, including providing financial support, enabled a relatively large number of impoverished youth to continue and complete their studies. ${ }^{24}$

In the interwar period, poor Jewish students were provided with material aid mainly by Jewish student associations, which obtained funds for this purpose from various sources. In addition to their philanthropic and self-help activities, they also attached great importance to cultural and educational activities and to the physical development of their members. They also constantly appealed to the authorities of individual L'viv universities in defence of the interests of Jewish students, protested against manifestations of anti-Semitism and attempts to limit the number of Jews admitted to higher education institutions, and so on. The phenomenon of limiting the number of Jewish youth

\footnotetext{
${ }^{21}$ Łapot 2016: 215.

${ }^{22}$ DALO, f. 110, op. 1, spr. 129: 2, 7.

${ }^{23}$ Ibid.: 9 .

${ }^{24}$ Rędziński, Wrona-Meryk 2013: 559.
} 
at L'viv's universities intensified especially at the end of the interwar period, which also affected the number of Jewish students' organizations. At the Jan Kazimierz University, where most Jews studied compared to other L'viv universities, their number decreased from 2,643 (43.3\% of the total number of students) in the academic year 1923/24 to only $323\left(10.5 \%\right.$ of the total number of students) in the academic year $1937 / 38 .^{25}$

After the World War I, student organizations existing in L'viv before the outbreak of the war quickly revived their activities. In the following years new organizations were also established. The emergence of new student organisations in L'viv, however, could only be seen in the 1920s. It was almost non-existent in the 1930s, due to the decreasing number of Jewish students in L'viv's universities at that time. Another phenomenon visible throughout the interwar period was that among Jewish student organizations there were definitely those that attracted Zionist youth. With the aim of integrating students, in 1922 individual Jewish students' organizations created a joint, community-based Executive Committee of Jewish Academic Self-help, Professional, Cultural, and Educational Institutions of the Polish Higher Schools of the L'viv Environment. ${ }^{26}$

As before World War I, in the interwar period, the most numerous and significant among Jewish student organizations was the Society of the Rygozoranów, which had been operating since $1868 .{ }^{27}$ In L'viv, it was also one of two Jewish students' organizations that had its own student house. It was located at 26a St. Teresa Street. The Society was headed by Dr. Adolf Chotiner (academic year 1918/1919), Dr. Beno Handel (1919/1920) and Dr. W. Kaczmarek (academic year 1919/1920). [...] Acker (1920/1921), Dr. Henryk Graf (1920/1921), Dr. Maurycy Morecki (1922/1923), Dr. Henryk Kahane (1922/1923), Dr. Henryk Graf (1923/1924, 1924/1925), Dr. Juliusz Zipper (1925/1926), Salomon Chuwel (1926/1927), Dr. Józef Kramer (1927/1928), Dr. Ozjasz Abraham (1928/1929). The Society's Audit Committee was chaired by the famous Zionist politician Emil Sommerstein, a Member of the Sejm (Polish Parliament). ${ }^{28}$

At the end of the interwar period and the outbreak of World War II, the society, which had 468 members in August 1939, was headed by Dawid Simelman. ${ }^{29}$

According to its articles of association, the society's primary objective was the "Provision of material support to its members." ${ }^{30}$ As indicated in the society's articles of association, this objective was pursued by enabling its members to use their own student dormitories, maintain dining rooms for them, grant them subsidies, grant them interestfree loans, provide them with free medical assistance and free clothing, and to create opportunities for them to earn money. In turn cultural and educational activities depended on maintaining a library, reading rooms of magazines, arranging readings and lectures etc. order to be able to carry out these activities. ${ }^{31}$ For example, in the academic year 1928/29 the reading room located in the Jewish Academic House subscribed to 30 magazines (5 in Hebrew, 8 in Yiddish, 12 in Polish, and 5 in German). ${ }^{32}$

\footnotetext{
${ }^{25}$ Langnas 1933: 7, 17; Draus 2007: 63, 67.

${ }^{26}$ Rędziński 2016: 586.

${ }^{27}$ Rędziński 2017: 261, 279.

${ }^{28}$ Sprawozdanie Roczne Wydziału Towarzystwa Rygorozantów 1929: 3, 12.

${ }^{29}$ DALO, f. 110, op. 1, spr. 140: 2.

${ }^{30}$ Ibid:: 57.

${ }^{31}$ Ibid.

32 Sprawozdanie Roczne Wydziału Towarzystwa Rygorozantów 1929: 20.
} 
The income for the society's activities, which consisted primarily in ensuring the proper functioning of the Jewish Academic House, came from contributions of the supporting members, who were mostly graduates of L'viv's universities; from the grants made by some Jewish communities, mainly from the south-east of Poland; by the L'viv City Hall; and the L'viv Brewery Company. In addition, every year there were collections among Jewish residents of towns and cities in south-eastern Poland. ${ }^{33}$

In the academic year 1928/29, 118 students lived in the Jewish Academic House. The canteen, on the other hand, was used by 250 people a day. Breakfast cost 12 groszy (the lowest-value Polish coin) and lunch 80 groszy. Those members of the Rygorozantów Association for whom there were no more places in the student dormitory were granted monthly benefits to rent an apartment in the amount of Zloty 15. In the academic year 1928/29, 20 such benefits were granted.

The Loan Fund was very popular among the members of the Rygorozantów Association. In the academic year 1928/29 it granted loans in the amount of Zloty 20,560. ${ }^{34}$ Poor members of the Society could also take advantage of therapeutic and recreational summer camps organized for them in Krynica, Piwniczna and Szczyrk. ${ }^{35}$

At the end of the interwar period, students of the Society of Rygorozantów, under the influence of the growing threat of war with Germany, joined the collections for the benefit of the National Defence Fund. In an atmosphere of tension which was becoming more and more evident in public life in Poland, a special rally was organized at the Academic House, which adopted a resolution "[...] on the readiness of academic youth to sacrifice blood." ${ }^{\prime 36}$

Another Jewish student organization with a student dormitory was the Academic Union of the United Youth, which consisted of Jewish youth aiming to assimilate or "unite" with the Polish nation. In 1928, the Hermann Foundation's Student House, run by the organization, could accommodate 100 students. Lunches valued at PLN 0.80 were distributed among 250 students in the canteen located there. Of these, $20 \%$ of the students paid much less for these lunches due to their difficult financial situation. ${ }^{37}$

The two Jewish student residences in L'viv were unable to satisfy all needs and solve all social problems. They could do so only to a small extent. For a large number of poor students, for whom there was no room anymore, the issue of renting and paying for their flats during the entire interwar period was still relevant and difficult to solve. This also applied to Jewish female students, so they took the initiative to build another house for Jewish female students. In order to accomplish this, in 1927 they founded the Society for the Construction of a House for Jewish Female Students of L'viv Higher Schools known as "The House of Jewish Female Students." In 1929 it had around 600 members. This initiative was also supported by the Society of Rygorozantów. The everyday activities of the society consisted mainly in granting aid for tuition, providing rent for apartments, and paying for meals. There was also a loan office which provided small

${ }^{33}$ Sprawozdanie Roczne Wydziatu Towarzystwa Rygorozantów 1927: 20; Sprawozdanie Roczne Wydziału Towarzystwa Rygorozantów 1928: 17.

${ }^{34}$ Sprawozdanie Roczne Wydziału Towarzystwa Rygorozantów 1929: 9-10, 13, 16.

${ }^{35}$ DALO, f. 110, op. 1, spr. 140: 2.

${ }^{36}$ Ibid.

${ }^{37}$ Rędziński 2016: 588. 
long-term and short-term loans, which attracted a great deal of interest. Unfortunately, the society did not manage to build a separate house for Jewish female students. The adverse effects of the economic crisis and the increasing pauperisation of the Jewish population meant that they were unable to collect adequate funds for this purpose. ${ }^{38}$

One important organization was the Mutual Assistance for Jewish Students of L'viv University of Technology, which integrated students of the University of Technology with its alumni. It was established in 1908 and after the World War I it was reopened in 1920. Almost all of the Jewish students of the university were members. In the academic year 1930/31 there were 310 ordinary members, recruited from Jewish students of the university. 361 Jews were studying at that time. The organization had a budget of about Zloty 30,000 and a library of about 3,000 books. Furthermore, at that time it also had around 200 supportive members, who were graduates of the L'viv Polytechnic already working there. It was mainly thanks to their contributions that self-help activities benefiting poor students were carried out. ${ }^{39}$

Some Jewish youth, including the poor, pursued studies abroad. The "Auxilium Academicum Judaicum" Association for the Aid of Jewish Students in Poland, which had been operating in L'viv since 1926, was very active with such youth in mind. Students studying abroad and benefiting from its assistance received monthly benefits ranging from Zloty 20 to 40. In 1926-1933, such aid was granted for a total amount of Zloty 36,337. It was used by students from L'viv and other areas including Brzeżany, Dolina, Gródek, Jarosław, Kołomyja, Kossów, Przemyśl, Rohatyn, Rożniatów, Rzeszów, Sambor, Skole, Stanisławów, Tarnopol, and Żórawno. ${ }^{40}$ Those who made up Auxilium Academicum Judaicum were aware of its great importance for the Jewish community. This significance was clearly articulated at the general assembly of this organization in L'viv at the beginning of September 1932, and the resolution adopted at that time was widely commented on by the Zionist press. "The General Assembly states that the financial aid provided by the Auxilium Academicum Judaicum in L'viv helped poor Jewish youth who were forced to study abroad, despite its small amount, was a very important budget item for these young people during their stay abroad." ${ }^{41}$

The Jewish student organizations in L'viv were also quite active on the level of philanthropy and self-help. These were The Society of Jewish Law Students, The Society of Jewish Medicine and Philosophers Students, The Jewish Fraternal Aid Section of the Academy of Veterinary Medicine, The Society for Mutual Assistance of Jewish Students of the Higher School of Foreign Trade, and above all The Society of Jewish Philosophers Students of the Jan Kazimierz University, which in 1923 had as many as 700 members. ${ }^{42}$ Of particular importance were the loan funds they operated to pay tuition fees and to provide assistance with fees for students who otherwise would have had to give up their studies.

Among those in need of material support were also those who later played an important role in science and public life. Among others, such people included Maurycy Horn,

\footnotetext{
${ }^{38}$ DALO, f. 110, op. 1, spr. 137: 4, 7-21.

${ }^{39}$ DALO, f. 110, op. 1, spr. 991: 13.

${ }^{40}$ Rędziński 2016: 582, 584.

${ }^{41}$ DALO, f. 110, op. 1, spr. 987: 16.

${ }^{42}$ Rędziński 2016: 586-587.
} 
later professor of history, in 1966-1968 rector of the Higher School of Pedagogy in Opole, and in 1987-1990 director of the Jewish Historical Institute in Warsaw. Being a thirdyear student of the Faculty of Humanities of the Society of Jewish Students of Philosophy of the Jan Kazimierz University in L'viv, due to his very difficult financial situation, on May 12, 1939 he asked for help to enable him to continue his studies. "The undersigned asks courteously for a grant in the amount of PLN 50 for the payment of the $3^{\text {rd }}$ instalment of the administrative fee. The petitioner supports his request by saying that he is the son of an unemployed language teacher who is unable to contribute to his maintenance. The applicant has to pass the last partial examination and if he fails to pay the tax, he is in danger of losing the opportunity to pass the exam and losing a year as a result. The petitioner makes a living from the private tutoring and has no funds to pay the tax." 43

As a result, individual Jewish student organizations played a very important role in students' lives by providing financial assistance to many poor youths, enabling them to continue and complete their studies. Thus, they significantly influenced the formation of the Jewish intelligentsia stratum, which was a strong element of the modernization processes in the Jewish community.

\section{Final remarks}

To sum up, we can say that the organisations in this paper as they undertook various forms of assistance which differed from the traditional are good examples of modernization processes among the Jewish population in large cities of Central and Eastern Europe.

In L'viv in the interwar period the predominantly philanthropic activities of the Zionist movement aiding pre-school children, school-age youth and students became very noticeable and important among the Jewish community. They gained an increasing degree of institutionalisation. They took different forms, but at the same time they shared a common feature, taking on a modern character different from the traditional. Neglected and orphaned Jewish children found a new home in them. It should also be emphasized that the scope and forms of activities carried out by these organizations resulted not only from the need to help the poor, constituted largely by the Jewish community and the neglected and orphaned children, but also from the desire to strengthen and deepen the modernization processes taking place within the Jewish community. In order to make it more and more similar to the non-Jewish environment, while at the same time striving to deepen the Jewish national consciousness and its own citizenship.

These already modern Jewish philanthropic organizations served the acculturationenhanced Jewish youth, helped young people undertake business activities and study in secular high schools and universities, while at the same time shaping their specific positive attitudes and behaviours. They supported individual development of children and youth, mutual empathy and sensitivity to the needs of others. They promoted good discipline and fostered progress in science. They also taught students a great deal about personal initiative and active citizenship.

\footnotetext{
${ }^{43}$ Ibid: 590.
} 
As a result, these organizations shaped young people who participated in building a modern society and were able to understand better the non-Jewish environment, while being reasonably and deeply aware of their belonging to the Jewish community.

\author{
Abbreviations \\ DALO - State Archives of L'viv Oblast
}

\title{
BIBLIOGRAPHY
}

\section{Archival sources}

DALO

Starostwo grodzkie we Lwowie, f. 110, op. 1, spr. 129. Starostwo grodzkie we Lwowie, f. 110, op. 1, spr. 132. Starostwo grodzkie we Lwowie, f. 110, op. 1, spr. 137. Starostwo grodzkie we Lwowie, f. 110, op. 1, spr. 140. Starostwo grodzkie we Lwowie, f. 110, op. 1, spr. 987. Starostwo grodzkie we Lwowie, f. 110, op. 1, spr. 991.

\section{Printed sources}

Sprawozdanie Roczne Wydziału Towarzystwa Rygorozantów za rok akademicki 1926/1927 (1927), Lwów.

Sprawozdanie Roczne Wydziału Towarzystwa Rygorozantów za rok akademicki 1927/1928 (1928), Lwów.

Sprawozdanie Roczne Wydzialu Towarzystwa Rygorozantów za rok akademicki 1928/1929 (1929), Lwów.

Sprawozdanie Towarzystwa Kolinji i Ochronek Ogrodniczych dla Dziatwy i Młodzieży Żydowskiej we Lwowie za rok 1926 i 1927 (1928), Lwów.

\section{Secondary literature}

Draus, J. (2007), Uniwersytet Jana Kazimierza we Lwowie 1918-1946. Portret kresowej uczelni, Kraków: $63-67$.

Jakimyszyn, A. (2014), Organized Recreation-Curative Stays for Adults and Children: An Analysis of Cases from the Lvov Area from the Interwar Period, Scripta Judaica Cracoviensia 12: 87-97.

Langnas, S. (1933), Żydzi a studia akademickie w Polsce w latach 1921-1931. Studium statystyczne, Lwów.

Łapot, M. (2016), Szkolnictwo żydowskie we Lwowie (1772-1939), Częstochowa.

Łapot, M. (2011), Z dziejów opieki nad żydowskim dzieckiem sierocym we Lwowie (1772-1939), Gliwice. Rędziński, K. (2016), Studenci żydowscy we Lwowie w latach 1918-1939, Prace Naukowe Akademii im. Jana Dlugosza w Częstochowie: Pedagogika 25: 581-601.

Rędziński, K. (2017), Żydowskie studenckie Towarzystwo Rygorozantów we Lwowie (1868-1914), Prace Naukowe Akademii im. Jana Dlugosza w Częstochowie: Pedagogika 26: 261-281.

Rędziński, K., Wrona-Meryk, I. (2013), Żydowskie stowarzyszenia studenckie we Lwowie (18901918), Prace Naukowe Akademii im. Jana Dlugosza w Częstochowie: Pedagogika 22: 545-560.

Wierzbieniec, W. (2000), Ludność żydowska Lwowa w okresie II Rzeczypospolitej, in: J. Basta, G. Zamoyski (eds.), Historia, archiwistyka, ludzie, Warszawa and Rzeszów: 289-317. 